\title{
PENETAPAN KADAR FENOLIK TOTAL DARI EKSTRAK ETANOL BUNGA ROSELLA BERWARNA MERAH (Hibiscus sabdariffa L.) DENGAN MENGGUNAKAN SPEKTROFOTOMETRI UV-Vis
}

\author{
Sulastri Sam¹, Abd.Malik dan Selpida Handayani \\ Fakultas Farmasi, Universitas Muslim Indonesia \\ 1atrigita99@yahoo.com
}

\begin{abstract}
Essential ingredients comfounds in roselle (Hibiscus sabdariffa L.) petals is anthocyanin pigments which include flavonoid that acts as an antioxidant. The aim of this research is to determine content of total phenolic of red roselle flowers (Hibiscus sabdariffa L.) ethanol extract. Sample as many one kilograms extracted by maceration method using ethanol 96\%. Resulty 127,03 grams extract. Total phenolic content determined by UV-Vis spectrophotometer at wavelenght $737 \mathrm{~nm}$ with gallic acid equivalent as standard reference with Folin-Ciocalteau reagent. The result show the rendamen of ethanolic extract is $12.703 \%$ with total phenolic content is $0.1853 \%$.
\end{abstract}

Keywords: Hibiscus sabdariffa L, Total phenolic, Folin-Ciocalteau method, UV-Vis spectrophotometer.

\section{PENDahuluan}

Rosella (Hibiscus sabdariffa L.) merupakan salah satu dari sekian banyak tanaman Indonesia yang memiliki banyak manfaat. Budidaya rosella (Hibiscus sabdariffa L.) khususnya yang berwarna merah di Indonesia sampai saat ini masih memiliki peluang dan prospek yang sangat baik. Hal ini didasarkan pada kondisi iklim dan tanah yang sesuai dan didukung dengan masih terbukanya pasar, baik untuk dalam maupun luar negeri. Meskipun di Indonesia rosella (Hibiscus sabdariffa L.) belum banyak dimanfaatkan, tetapi di negara lain telah dimanfaatkan sejak lama. Selain dimanfaatkan sebagai makanan, rosella (Hibiscus sabdariffa L.) juga bermanfaat sebagai pangan yang berkhasiat bagi kesehatan (Maryani dan Kristiana, 2008).

Kelopak bunga rosella (Hibiscus sabdariffa L.) mengandung protein, lemak, serat, mineral seperti kalsium, fosfor, dan besi, serta vitamin seperti thiamin, riboflavin, niasin, dan asam skorbat. Selain itu mengandung senyawa karotenoid, flavonoid, dan alkaloid. Manfaat ekstrak rosella (Hibiscus sabdariffa L.) bagi kesehatan adalah sebagai antihipertensi, antihiperlipidemia, hepatoprotektiv, antikanker, dan memiliki aktivitas antioksidan (Mahadevan et al., 2009). Pada bunga rosella (Hibiscus sabdariffa L.) senyawa yang paling berperan dalam pengobatan adalah senyawa fenolik.

Senyawa fenolik merupakan senyawa antioksidan alami yang terdapat dalam bentuk senyawa aktif dalam makanan. Senyawa fenolik dapat mencegah berbagai jenis penyakit, seperti kanker dan jantung koroner. Senyawa ini pun berperan sebagai faktor pelindung terhadap bahaya oksidasi pada tubuh manusia (Widia, 2007). Secara umum senyawa fenolik sederhana memiliki sifat bakterisidal, antiseptik dan antihelmentik (Seafast, 2012).

Penelitian kadar fenolik total yang terkandung dalam tanaman rosella (Hibiscus sabdariffa L.) perlu dilakukan. Dengan demikian pemanfaatan tanaman rosella (Hibiscus sabdariffa L.) dapat lebih maksimal untuk dijadikan sebagai alternatif pengobatan herbal dalam penyembuhan berbagai macam penyakit, karena dengan melihat kadar fenolik total yang terkandung dalam ekstrak bunga rosella (Hibiscus sabdariffa L.) maka dapat diperkirakan besar aktivitas antioksidannya. Disamping itu, penetapan kadar fenolik total pada kelopak bunga rosella (Hibiscus sabdariffa L.) untuk mempertegas kandungan fenolik total pada bunga rosella (Hibiscus sabdariffa L.) yang bermanfaat sebagai data penelitian dan pengembangan obat bahan alam.

\section{METODE PENELITIAN}

A. Pengambilan dan Pengolahan Sampel

Sampel bunga rosella (Hibiscus sabdariffa

L.) berwarna merah dikumpulkan pada pagi hari pukul 09.00 dengan cara memetik daun dari cabang. Bunga rosella (Hibiscus sabdariffa L.) berwarna merah di ambil dari tanaman yang sehat dan segar yang ditunjukkan dengan tidak adanya kerusakan pada bentuk daun. Sampel yang digunakan diambil dari Kabupaten Kediri, Provinsi Jawa Timur.

Bunga rosella (Hibiscus sabdariffa L.) berwarna merah yang telah diperoleh dibersihkan dari kotoran yang melekat dengan cara dicuci dengan air mengalir kemudian dikeringkan dengan cara dianginanginkan pada tempat yang tidak terkena sinar matahari secara langsung kemudian dirajang kecilkecil, diserbukkan dan siap untuk diekstraksi. 


\section{B. Ekstraksi Sampel}

Ditimbang 170 gram bunga rosella (Hibiscus sabdariffa L.) berwarna merah, kemudian dimasukan serbuk bunga rosella berwarna merah yang akan disari kedalam bejana maserasi. Dituang secara perlahan pelarut etanol kedalam bejana maserasi yang berisi serbuk bunga rosella merah. Kemudian biarkan cairan penyari merendam serbuk simplisia selama 3 hari sesekali dilakukan pengadukkan, dilakukan remaserasi hingga bening. Selanjutnya disaring ke dalam wadah baru sehingga diperoleh ekstrak cair. Hasil penyarian dari ekstrak diuapkan dengan menggunakan rotavapor dibawah titik didih hingga diperoleh ekstrak kental (Ditjen POM, 2000).

\section{Pembuatan Reagen $\mathrm{Na}_{2} \mathrm{CO}_{3} 7 \%$}

Ditimbang sebanyak 3,5 gram $\mathrm{Na}_{2} \mathrm{CO}_{3}$ kemudian dilarutkan dengan aquadest steril hingga $50 \mathrm{ml}$.

\section{Penetapan Kadar Fenolik Total}

Penetapan kadar pada ekstrak etanol bunga rosella (Hibiscus sabdariffa L.) berwarna merah merujuk pada prosedur Chun et al (2003) dengan beberapa modifikasi.

1. Penentuan Kadar Fenolik Total

a. Pembuatan larutan standar asam galat.

Larutan standar asam gallat $1000 \mathrm{ppm}$ dibuat dengan menimbang $10 \mathrm{mg}$ asam gallat dilarutkan dengan etanol $96 \%$ hingga volume $10 \mathrm{~mL}$. Dari larutan stock dipipet sebanyak $0,25 \mathrm{~mL}$ diencerkan dengan etanol $96 \%$ hingga volume $25 \mathrm{~mL}$ hingga dihasilkan konsentrasi $10 \mathrm{ppm}$. Dari larutan tersebut dipipet 1, 2, 3, dan $4 \mathrm{~mL}$ dan dicukupkan dengan etanol $96 \%$ hingga $10 \mathrm{~mL}$, sehingga dihasilkan konsentrasi 1, 2, 3, dan 4 ppm.

b. Pengukuran larutan standar asam galat
Untuk masing-masing konsentrasi 1, 2, 3, dan 4 ppm ditambahkan dengan $0,4 \mathrm{~mL}$ reagen FolinCiocalteau dikocok dan dibiarkan 8 menit, tambahkan 4,0 mL larutan $\mathrm{Na}_{2} \mathrm{CO}_{3} 7 \%$ kocok hingga homogen. Tambahkan aquades steril hingga $10 \mathrm{~mL}$ dan diamkan selama 2 jam pada suhu ruangan. Ukur serapan pada panjang gelombang serapan maksimum $730 \mathrm{~nm}$, lalu buat kurva kalibrasinya, hubungan antara konsentrasi asam galat $(\mu \mathrm{g} / \mathrm{mL})$ dengan absorbansi.

c. Pembuatan larutan ekstrak bunga rosella (Hibiscus sabdariffa L.) berwarna merah

Larutan ekstrak bunga rosella rosella (Hibiscus sabdariffa L.) berwarna merah dibuat dengan cara menimbang $10 \mathrm{mg}$ kemudian dilarutkan dengan $10 \mathrm{~mL}$ etanol $96 \%$.

d. Penetapan fenolik total ekstrak bunga rosella (Hibiscus sabdariffa L.) berwarna merah

Dipipet sebanyak $0,5 \mathrm{~mL}$ larutan dari ekstrak etanol bunga rosella (Hibiscus sabdariffa L.) berwarna merah, ekstrak sampel ditambahkan dengan $0,4 \mathrm{~mL}$ reagen Folin-Ciocalteau (campuran asam fosfomolibdat dan fosfotungstat ) dikocok dan dibiarkan 4-8 menit, tambahkan 4,0 mL larutan $\mathrm{Na}_{2} \mathrm{CO}_{3} 7 \%$ kocok hingga homogen. Tambahkan aquadest steril hingga $10 \mathrm{~mL}$ dan diamkan selama 2 jam pada suhu ruangan. Ukur serapan pada panjang gelombang serapan maksimum $750 \mathrm{~nm}$ yang akan memberikan komplek biru. Lakukan 3 kali pengulangan sehingga kadar fenolik yang diperoleh hasilnya didapat sebagai $\mathrm{mg}$ ekuivalen asam galat/100 mg sampel segar.

\section{E. Analisis Data}

Pengolahan data yang dihasilkan terlebih dahulu dilakukan dengan metode kurva standar, regresi linier $\mathrm{y}=\mathrm{bx}+\mathrm{a}$ dibuat berdasarkan data absorbansi dan konsentrasi dari larutan standar.

\section{III.HASIL DAN PEMBAHASAN \\ A. Hasil Penelitian}

Tabel 1. Hasil rendamen ekstrak etanol bunga Rosella (Hibiscus sabdariffa L.) kelopak berwarna merah

\begin{tabular}{cccccc}
\hline No. & Sampel & $\begin{array}{c}\text { Bobot } \\
\text { simplisia }(\mathbf{g})\end{array}$ & $\begin{array}{c}\text { Jumlah } \\
\text { pelarut }(\mathbf{m L})\end{array}$ & $\begin{array}{c}\text { Hasil ekstrak } \\
(\mathbf{g})\end{array}$ & $\begin{array}{c}\text { Rendamen } \\
\text { ekstrak }(\%)\end{array}$ \\
\hline 1. & Kelopak Merah & 1000 & 3500 & 127,03 & 12,703 \\
\hline
\end{tabular}


Tabel 2. Hasil uji Kualitatif Adanya Senyawa Fenolik ekstrak etanol bunga rosella (Hibiscus sabdariffa L.) merah

\begin{tabular}{ccc}
\hline Sampel & $\begin{array}{c}\text { Uji Fenolik } \\
\text { FeCl3 }\end{array}$ & $\begin{array}{c}\text { Hasil } \\
\text { Pengamatan }\end{array}$ \\
\hline Bunga Rosella & Biru & + \\
$\begin{array}{c}\text { Hibiscus sabdariffa } \\
\text { L.) Merah }\end{array}$ & Kehitaman & + \\
\hline
\end{tabular}

Keterangan: $(+)=$ Menunjukkan adanya Fenolik.

Tabel 3. Pengukuran absorbansi baku asam galat.

\begin{tabular}{ccc}
\hline No & $\begin{array}{c}\text { Konsentrasi Asam } \\
\text { Galat (ppm) }\end{array}$ & Absorbansi \\
\hline 1 & 1 & 0,256 \\
2 & 2 & 0,505 \\
3 & 3 & 0,723 \\
4 & 4 & 0,933 \\
5 & 5 & 1,295 \\
\hline
\end{tabular}

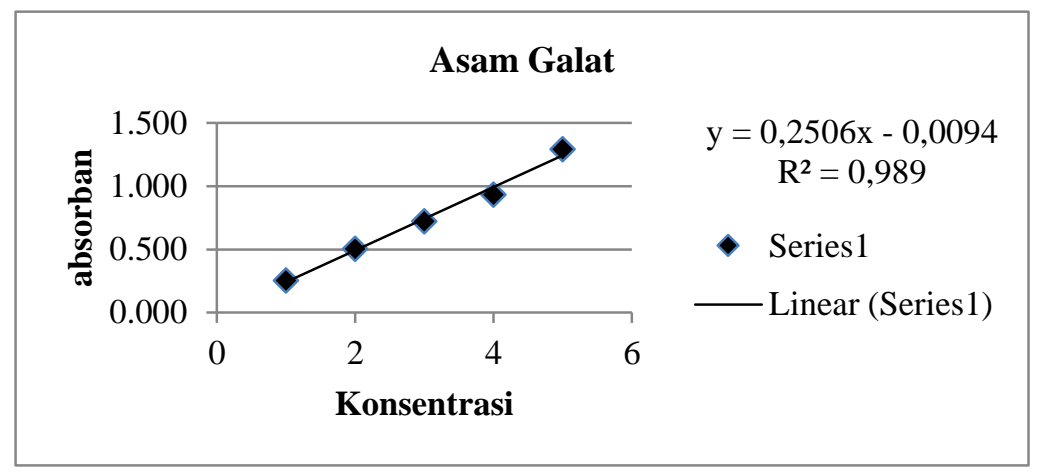

Gambar 1. Kurva linear asam galat vs absorbansi.

Tabel 4. Nilai Absorbansi sampel ekstrak etanol bunga rosella (Hibiscus sabdariffa L.) merah.

\begin{tabular}{ccc}
\hline No & Replikasi & Absorbansi $(\chi \mathbf{7 3 7} \mathbf{n m})$ \\
\hline 1 & 1 & 0,4535 \\
2 & 2 & 0,4551 \\
3 & 3 & 0,4569 \\
\hline
\end{tabular}

Tabel 5. Hasil pengukuran kadar fenolik total ekstrak etanol bunga rosella (Hibiscus sabdariffa L.) merah.

\begin{tabular}{ccccccc}
\hline Sampel & Replikasi & $\begin{array}{c}\text { Absorbansi } \\
(\mathbf{Y})\end{array}$ & $\begin{array}{c}\text { Kandungan } \\
\text { Fenolik awal } \\
\text { (mg/L) }\end{array}$ & $\begin{array}{c}\text { Fenolik total } \\
\text { (mg GAE/g } \\
\text { eks.) }\end{array}$ & $\begin{array}{c}\text { Rata- rata } \\
\text { kandungan } \\
\text { fenolik total } \\
\text { (mg GAE/g } \\
\text { eks.) }\end{array}$ & $\begin{array}{c}\text { \% kadar } \\
\text { fenolik }\end{array}$ \\
\hline Bunga & 1 & 0,4535 & 0,0018471 & 1,8471 & 1,8537 & 0,1853 \\
Rosella & 2 & 0,4551 & 0,0018535 & 1,8535 & & \\
merah & 3 & 0,4569 & 0,0018607 & 1,8607 & & \\
\hline
\end{tabular}

\section{B. Pembahasan}

Tanaman Rosella merah (Hibiscus Sabdariffa L.) merupakan tanaman yang sering digunakan masyarakat pada umumnya sebagai tanaman obat. Bagian yang paling banyak digunakan pada tananman Rosella merah (Hibiscus Sabdariffa
L.) ini adalah kelopaknya. Pada penelitian ini digunakan kelopak bunga Rosella merah (Hibiscus Sabdariffa L.) yang diambil langsung dari Lahan Gunung Pohsarung, Kecamatan Semen, Kabupaten Kediri (Jawa Timur). 
Kelopak bunga Rosella merah (Hibiscus Sabdariffa L.) mengandung senyawa-senyawa yang banyak berperan dalam proses pengobatan seperti senyawa fenolik. Kandungan penting yang terdapat pada kelopak bunga rosella adalah pigmen antosianin yang membentuk flavonoid yang berperan sebagai antioksidan. Flavonoid rosella terdiri flavanols dan pigmen antosianin. Antosianin pada kelopak bunga rosella berada dalam bentuk glukosida yang terdiri dari cyanidin-3-sambubioside, delphinidin-3-glucose, dan delphinidin-3-sambubioside. Sementara itu, flavonols terdiri dari gossypetin, hibiscetin, dan quercetia (Mardiah dkk, 2009).

Kelopak bunga rosella(Hibiscus sabdariffa L.) juga mengandung alkaloid, L-ascorbic acid, anisaldehid, antosianin, beta karoten, protocathecuic acid, beta sitosterol, asam sitrat, galaktosa, polifenol, cyaniding-3-rutinoside, mukopolisakarida, pektin, polisakarida, asam stearat, dan lilin (Hirunpanich, 2005). Semakin pekat warna merah pada kelopak bunga rosela, rasanya akan semakin asam dan kandungan antosianin (sebagai antioksidan) semakin tinggi (Setiawan, 2010).

Masyarakat tradisional di berbagai negara telah memanfaatkan tanaman rosella untuk mengatasi berbagai penyakit dan masalah kesehatan. Pemanfaatan tanaman rosela ini berkaitan dengan fungsinya sebagai antiseptik, aprodisiak (meningkatkan gairah seksual), astringen, demulcent (menetralisir asam lambung), diuretik, purgatif, anthelmintik, refrigerant (efek mendinginkan), resolvent, sedatif, tonik, serta mengobati kanker, batuk, dispepsia, disuria, demam, hangover (kembung perut), hipertensi, neurosis, sariawan, dan mencegah penyakit hati (Mardiah dkk, 2009). Kelopak bunga rosella dapat digunakan untuk mencegah perkembangan atherosklerosis dan komplikasi kardiovaskuler akibat diabetes (Farombi et al, 2007). Di antara banyak khasiatnya, kelopak bunga rosella diunggulkan sebagai herba antikanker, antihipertensi, dan antidiabetes (Mardiah dkk, 2009).

Kelopak bunga Rosella merah merah (Hibiscus Sabdariffa L.) yang telah diserbukkan sebanyak 1000 gr kemudian dimaserasi dengan menggunakan pelarut etanol $96 \%$ sehingga menghasilkan 127,03 gram ekstrak etanol, digunakan pelarut etanol karena etanol bersifat semi polar sehingga memudahkan penarikan senyawa yang polar dan non polar dimana senyawa fenolik yang ada pada sampel ada yang bersifat non polar dan ada yang polar. Sampel diekstraksi dengan metode maserasi karena tekstur dari kelopak bunga rosella (Hibiscus Sabdariffa L.) lunak, jadi diekstraksi dengan metode maserasi (cara dingin) sehingga tidak merusak kandungan kimia dalam kelopak bunga rosella (Hibiscus Sabdariffa L.), dimana kadar antosianin pada kelopak bunga rosella (Hibiscus Sabdariffa L.) berkurang jika dilakukan pemanasan.

Dilakukan uji kualitatif dengan menggunakan lempeng KLT menggunakan eluen BAA (n-butanol : asam asetat : aquadest) $(4: 1: 5)$ kemudian disemprotkan dengan $\mathrm{FeCl}_{3}$. Didapatkan hasil ekstrak etanol rosella merah (Hibiscus Sabdariffa L.) positif mengandung senyawa fenolik yang ditandai dengan adanya noda berwarna biru kehitaman pada lempeng. Terjadi perubahan pada lempeng karena adanya komposisi pada larutan $\mathrm{FeCl}_{3}$ yang membentuk kompleks dengan senyawa fenolik sehingga terbentuk warna biru kehitaman.

Dilanjutkan dengan uji kuantitatif untuk mengetahui kadar fenolik total pada ekstrak etanol kelopak bunga Rosella merah (Hibiscus Sabdariffa L.), menggunakan metode Folin-Ciocalteau cara Chun et al. (2003), dan sebagai standar digunakan larutan asam galat atau asam 3,4,5-trihidroksibenzoat $\left(\mathrm{C}_{6} \mathrm{H}_{2}(\mathrm{OH})_{3} \mathrm{CO}_{2} \mathrm{H}\right)($ Apsari dan Susanti, 2011) karena asam galat merupakan turunan dari asam hidroksibenzoad yang tergolong asam fenolik sederhana dan juga sebagai standar yang ketersediaan substansi yang stabil dan murni (Rahmawati, 2009). Dengan variasi konsentrasi $1 ; 2 ; 3 ; 4 ; 5 \mathrm{ppm}$. Pada penetapan kadar juga digunakan $\mathrm{Na}_{2} \mathrm{CO}_{3}$, dalam pembuatan $\mathrm{Na}_{2} \mathrm{CO}_{3}$, ditimbang sebanyak 3,5 gram $\mathrm{Na}_{2} \mathrm{CO}_{3}$ kemudian dilarutkan dengan $20 \mathrm{~mL}$ aquadest steril sampai larut senpurna. Setelah itu dicukupkan sampai $50 \mathrm{ml}$.

Pembanding yang digunakan pada penetapan kadar ekstrak etanol kelopak bunga Rosella merah ( Hibiscus Sabdariffa L. ) adalah asam galat. Selain asam galat,asam tanat juga bisa digunakan sebagai pembanding pada penetapan kadar fenolik, karena asam galat memiliki gugus hidroksil 3 sedangkan asam tanat hanya memiliki gugus hidroksil 2, semakin banyak gugus hidroksil, maka semakin reaktif digunakan sebagai antioksidan, selain itu asam galat juga merupakan turunan fenolik sederhana. Pembuatan larutan standar asam gallat dilakukan dengan melarutkan $10 \mathrm{mg}$ asam galat kedalam etanol $96 \%$ menggunakan labu takar $10 \mathrm{~mL}$ hinggam menghasilkan konsentrasi 1000 ppm. Dari larutan stock dipipet sebanyak $0,25 \mathrm{~mL}$ diencerkan dengan etanol $96 \%$ hingga volume $25 \mathrm{~mL}$ hingga dihasilkan konsentrasi $10 \mathrm{ppm}$. Dari larutan tersebut dipipet 1,2, 3, 4 dan $5 \mathrm{~mL}$ dan dicukupkan dengan etanol $96 \%$ hingga $10 \mathrm{~mL}$, sehingga dihasilkan konsentrasi 1,2 , 3, 4 dan 5 ppm. Untuk pembuatan kurva baku masing- masing tabung reaksi. Selanjutnya untuk masing- masing larutan standar tersebut ditambahkan dengan $0,4 \mathrm{~mL}$ reagen Folin-Ciocalteau dan diinkubasi selama 4-8 menit, reagen folin-Ciocaltaeu ini merupakan reagen pengoksidasi berupa larutan berwarna kuning kemudian senyawa fenolik pada 
sampel akan dioksidasi oleh molibdat tungstat yang merupakan komponen dari folin-ciocalteau (bekerja mereduksi gugus hidroksil) sehingga membentuk senyawa berwarna biru yang dapat diukur pada sampai panjang gelombang $765 \mathrm{~nm}$. Kemudian larutan ditambahkan dengan 4,0 $\mathrm{mL} \quad \mathrm{Na}_{2} \mathrm{CO}_{3} \quad 7 \%$ karena folin hanya bereaksi disuasana basa (dalam suasana basa folin mengalami batokrom atau pergeseran panjang gelombang kepanjang gelombang yang lebih maksimal) sehingga ditambahkan $\mathrm{Na}_{2} \mathrm{CO}_{3}$ untuk membuat suasana basa (folin bersifat asam ketika ditambahkan pada sampel / ekstrak), lalu ditambahkan dengan aquadest steril sampai batas tanda. Setelah 2 jam inkubasi, absorbansi larutan diukur pada panjang gelombang $737 \mathrm{~nm}$ dengan larutan blanko air suling dan reagen Folin-Ciocalteau.

Pada penetapan kadar pada ekstrak etanol bunga rosella (Hibiscus sabdariffa L.) merah dilakukan dengan beberapa modifikasi yaitu sampel ekstrak etanol bunga rosella (Hibiscus sabdariffa L.) merah dibuat dengan cara menimbang $10 \mathrm{mg}$ kemudian dilarutkan dengan $10 \mathrm{~mL}$ etanol $96 \%$ dan dihomogenisasi. Dipipet sebanyak $1 \mathrm{~mL}$ kemudian dicukupkan dengan $10 \mathrm{ml}$ etanol 96\%. Selanjutnya dipipet $1 \mathrm{ml}$ dari larutan tersebut untuk tiga replikasi. Masing- masing larutan ditambahkan dengan 0,4 mL reagen Folin-Ciocalteau dikocok dan dibiarkan 4-8 menit, tambahkan 4,0 mL larutan $\mathrm{Na}_{2} \mathrm{CO}_{3} 7 \%$ kocok hingga homogen. Tambahkan aquadest steril hingga $10 \mathrm{~mL}$ dan diamkan selama 2 jam pada suhu ruangan. Ukur serapan pada panjang gelombang serapan maksimum $737 \mathrm{~nm}$ yang akan memberikan kompleks biru. Lakukan 3 kali pengulangan sehingga kadar fenol yang diperoleh hasilnya didapat sebagai mg ekuivalen asam galat/100 mg sampel segar. Nilai fenolik total dinyatakan dalam Gallic Equivalents (GAE) tiap $100 \mathrm{~g}$ berat kering ekstrak etanol bunga rosella merah g GAE/100 g berat kering ektrak etanol bunga rosella merah.

Hasil pengukuran absorbansi pembanding asam galat diplotkan terhadap konsentrasinya, sehingga diperoleh kurva linear seperti pada gambar 3. Nilai $\mathrm{R}^{2}$ yaitu 0,989 menunjukkan linearitas yang cukup baik, maka persamaan regresi linear $(\mathrm{y}=$ 0,2506x -0,0094) dapat digunakan untuk penetapan kadar fenolik total sampel bunga rosella ( Hibiscus Sabdariffa L. ) berwarna merah. Kadar fenolik total bunga rosella (Hibiscus Sabdariffa L.) berwarna merah untuk daerah Lahan Gunung Pohsarang, Kecamatan Semen, Kabupaten Kediri (Jawa Timur) adalah $1,8537 \mathrm{mg} \mathrm{GAE} / \mathrm{g}$ atau $0,1853 \%$.

\section{KESIMPULAN}

Dari penelitian yang telah dilakukan didapatkan hasil ekstrak etanol bunga rosella merah
(Hibiscus Sabdariffa L.) memiliki kandungan fenolik total sebesar $0,1853 \%$.

\section{DAFTAR PUSTAKA}

Ditjen POM. (1986). Sediaan Galenik. Jakarta: Departemen Kesehatan Republik Indonesia.

Farombi, E.O., Ige, O.O. 2007. Hypolipidemic and Antioxidant effects of ethanolic extract from dried calyx of Hibiscus sabdariffa in alloxaninduceddiabeticrats.http://pt.wkhealth.com/pt /re/fncp/abstract.00003837_200712000_0000 5. htm;jsession (11 oktober 2009).

Fessenden. (1986). Kimia Organik. (edisi 2). jilid 2. Jakarta: Erlangga.

Gritter, Roy J. dkk. (1991). Pengantar Kromatografi. (Edisi II). Bandung: Penerbit ITB.

Harborne. (1996). Metode Fitokimia: Penuntun Cara Modern Menganalisa Tumbuhan. Bandung: ITB.

Hirunpanich, V., Utaipat A, Noppawan, P. M., Nuntavan, B., Hitoshi, S., Angkana, H., Chuthamanee, S. 2005. Antioxidant effect of aqueous extracts from dried calyx of Hibiscus sabdariffa linn (roselle) in vitro using rat low-density lipoprotein (LDL). Bio. Pharm. Bull. 28(3): 481-484

Khopkar, S.M. (2008). Konsep dasar Kimia Analitik. Jakarta: UI Press.

Laurence, J.D. 12 Juli 2013. Hibiscus sabdariffa. 17 September 2013 http://www.itis.gov/servlet/SingleRpt/Single Rpt?search_topic $=$ TSN\&search_value $=5030$ $\underline{01}$

Mahadevan N, Shivali, Kamboj P (2009) Hibiscus sabdariffa Linn. an overview. Natural Product Radiance Vol 8(1): 77-83.

Mardiah, Hasibuan S, Rahayu A, Ashadi RW (2009) Budi daya dan pengolahan rosela si merah segudang manfaat. AgroMedia Pustaka, Jakarta.

Maryani H, Kristiana L (2008) Khasiat dan manfaat rosela. AgroMedia Pustaka, Jakarta.

Maryani, H. \& Kristiana, L. (2005). Khasiat dan Manfaat Rosela. Jakarta: AgroMedia Pustaka.

Ningsih, Widia. (2007). Evaluasi Senyawa Fenolik ( Asam Ferulat dan Asam P-Kumarat Pada Biji, Kecambah dan tempe Kacang Tunggak (Vigna Unguiculata) (skripsi). Bogor : Institut Pertanian Bogor.

Robinson, T. (1995). Kandungan Organik Tumbuhan Tinggi. (Edisi VI). Penerjemah: K. Padmawinata. Bandung: ITB Press. 
Seafast. 2012. Biosintesis Senyawa Fenolik. 21 September 2013. seafast.ipb.ac.idtpcprojectwp2-biosintesis.pdf.

Setiawan, Rudi. (2010). Pengaruh Pemberian Ekstrak Bunga Rosella (Hibiscus Sabdariffa L) Terhadap Penurunan Kadar Glukosa Gula Putih Yang Diinduksi Aloksan (Skripsi). Surakarta: Universitas Sebelas Maret.

Tobo, Fachruddin. (2001). Buku Pegangan Laboratorium Fitokimia I. Makassar: Laboratorium Fitokimia Jurusan Farmasi Unhas.

Underwood. (2001). Analisis Kimia Kuantitatif. Jakarta: Erlangga.

Widia, Ningsih. (2007). Evaluasi Senyawa Fenolik (Asam Ferulat dan Asam p-Kumarat ) Pada biji, Kecambah \& Tempe Kacang Tunggak (Vigna unguiculata) (Skripsi). Bogor: Institut Pertanian Bogor. 